\title{
American ntiquity
}

A Quarterly Review of American Archaeology

\section{Contents}

EdrTORIAL . . . . . . . . . . . . . . . 97

The Direct-Historical A pproach in California Archaeology. RoBerT

F. Heizer . . . . . . . . . . . . . . . . 98

Reconnaissance of the Central San Joaquin Valley. Gordon W.

Hewes . . . . . . . . . . . . . . . 123

The Origin and Authenticity of an Atlatl and an Atlatl Dart from

Lassen County, California. Franklin Fenenga and RoberT

F. Heizer . . . . . . . . . . . . . . . 134

Excavations in the Calapuya Mounds of the Willamette Valley,

Oregon. William S. LaUghliN . . . . . . . . . 147

Observations Concerning the "Red Paint Culture". Wendell S.

HADLOCK . . . . . . . . . . . . . . . 156

Facts and Comments

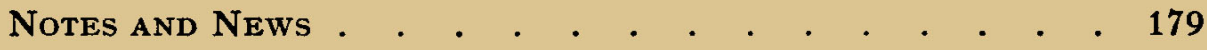

Book Reviews $\quad . \quad$. . . . . . . . . . . . . See Cover III

Annual Meeting of the Society for American Archaeology 202

Some Recent Publications . . . . . . . . . . . . . 207

AMERICAN ANTIQUITY IS INDEXED IN THE INTERNATIONAL INDEX

\section{Published by the \\ Society for American Archaeology}




\section{SOCIETY FOR A MERICAN A R CHA EOLOGY}

\section{OFFICERS}

President: GLENN A. BlACK, Indiana Historical Society, Indianapolis, Indiana.

Vice-President: EmIL W. Haury, University of Arizona, Tucson, Arizona.

Secretary-Treasurer: ThORNE DeuEL, Illinois State Museum, Springfield, Illinois.

Editor: Douglas S. Bxers, Phillips Academy, Andover, Massachusetts.

Associate Editor: George C. VaIllant, American Museum of Natural History, New York City.

Assistant Editors:

Henry B. Collins, Jr., Arctic Geographical Area.

E. W. Girford, Pacific Coast Geographical Area.

ERIK K. REED, Southwestern Geographical Area.

Waldo R. Wedel, Plains Geographical Area.

James B. Griffin, Northern Mississippi Geographical Area.

W. A. Ritchie, Northeastern Geographical Area.

Wm. S. WebB, Southeastern Geographical Area.

J. Alden MAson, Middle American Geographical Area.

WeNDELl C. BENNETT, South American Geographical Area.

F. H. H. RoberTs, JR., Early Man in America.

Frederick Johnson, The Notebook.

Members of Council: The President, Vice-President, Secretary-Treasurer, Editor, and Harold S. Colton, JAmes Ford, James B. Griffin, A. T. Hill, Charles R. Keyes, Frederica de Laguna, M. R. Harrington, E. B. Sayles.

AMERICAN ANTIQurTy is published at 450-454 Ahnaip Street, Menasha, Wisconsin, quarterly in the months of January, April, July. and October by the Society for American Archaeology. Subscription only by membership in the Society for American Archaeology (annual dues $\$ 3.00)$; includes the quarterly issues of AMERICAN ANTIQUiTy and other releases as issued.

Entered as second-class matter July 22, 1935, at the post office at Menasha, Wisconsin, under the Act of March 3, 1879.

Contributions and publications for review should be sent to the Editor, Douglas S. Byers.

Subscriptions and orders for back numbers should be addressed to the Secretary-Treasurer, Thorne Deuel. 